\title{
Modeling and Forecasting the Volatility of Returns in the Infrastructure Sector in Emerging Markets
}

\author{
Rabson MAGWEVA*, Mabutho SIBANDA**
}

Received: October 21, 2019

Revised: March 21, 2020

Accepted: April 23, 2020.

\begin{abstract}
Understanding the volatility behaviour of specific sectors of the economy enables investors to formulate workable investment strategies, and policy-makers to formulate policies that dampen excess volatility. This study examined the volatility features of the infrastructure sector in emerging markets. The features assessed were the GARCH effects, volatility persistence, and leverage effects. EGARCH and GJRGARCH models of order one under normal and non-normal error distributions were employed to unpack the volatility behaviour of infrastructure returns in emerging markets. The results from both models under all distributions indicated the existence of GARCH effects, volatility clustering, volatility persistence, and leverage effects in the infrastructure sector in emerging nations. This implies that past conditional variance is significant in determining current conditional variance, thereby rendering forecasting a worthwhile task. The findings also suggest that investors interested in the infrastructure sector in emerging markets should incorporate leverage effects in their estimation of value-at-risk. Furthermore, they should focus on factors other than mean-variance portfolio optimization and consider leverage effects, excess kurtosis, and skewness when making investment decisions. Finally, investors in the infrastructure sector in emerging markets are encouraged to formulate hedging strategies as they are exposed to significant risk and uncertainty.
\end{abstract}

Keywords: infrastructure, volatility, modeling, forecasting, emerging markets

JEL Code Classification: 018, D81, G17, G11

UDC: 338.012

DOI: https://doi.org/10.17015/ejbe.2020.025.03

\footnotetext{
${ }^{*}$ Corresponding author, PhD candidate, College of Law \& Management Studies, University of KwaZulu-Natal, South Africa. E-mail: rmagweva@gzu.ac.zw

** Dean of School of Accounting, Economics and Finance, University of KwaZulu-Natal, South Africa. E-mail: sibandam@ukzn.ac.za
}

Copyright (C, 2020 Ala-Too International University. 


\section{Introduction}

The volatility of financial markets is becoming increasingly important to investors and policy-makers, especially after the global financial crises of 2007/8. Understanding the volatility behaviour of financial markets assists policy-makers in designing regulations that dampen the effects of such behaviour on domestic financial markets (Uyaebo, Atoi, \& Farida, 2015). As a crude measure of risk (and economic stability) as well as investor sentiments, volatility plays an influential role in financial markets when it comes to the management of risk (Value at Risk computations), option pricing, allocation of assets and management of portfolios (Pati, Barai \& Rajib, 2018; John \& Amudha, 2019).

The volatility of financial markets is an essential issue in emerging economies where financial markets are exposed to violent external shocks and domestic upheaval resulting from political and economic factors, among other factors (Wilson, Ugwuanyi, \& Nwaocha, 2019). Forecasting and modeling volatility in emerging markets is thus crucial, not only for international investors but all economic agents as it affects real economic activities, company investment and capital structure decisions, consumer spending and saving patterns, portfolio revisions and the performance of stock markets (Rahahleh \& Kao, 2018). Mashamba and Magweva (2019) noted that high volatility in financial markets makes raising long term capital very costly and difficult and ultimately results in the misallocation of resources. Volatile markets erode investor confidence and make financial assets unattractive due to erratic and wild price movements of such assets (Wilson et al., 2019; Islam, 2013). However, volatility is a double-edged sword as extremely volatile assets and securities like crypto-currencies, foreign currency, and listed shares can generate abnormal returns in the short run. As such, investors need to know how to model and predict volatility so that they benefit from (or hedge) market swings.

Risk-averse investors are in constant search of assets and investments which produce less volatile and steady returns. Such investments will enable investors to meet their long and short term objectives without difficulties. Given its financial and economic characteristics, the infrastructure sector might be such an investment. The sector also enjoys monopolistic and oligopolistic powers (pricing powers), inelastic demand (for products), and inflation-linked price adjustments (from concessions and agreements). The sector is defensive and less responsive to economic and business cycles as it provides products that are the backbone of any economy and are rarely substitutable. Consequently, the infrastructure sector's returns and stock prices are expected to be stable and less volatile than those in other economic sectors.

However, the deregulation of this sector is gaining momentum, and given its political importance, government interference in the pricing of utilities and infrastructure products and services is likely (Nguyen, 2019). Furthermore, volatility in stock markets is not only driven by economic fundamentals (such as changes in the interest rate policy and earning power) but also by irrationality and behavioural traits and 
biases (such as overconfidence and over-reaction to negative news) among investors and fund managers (Takemura et al., 2018). This could result in the infrastructure sector exhibiting similar risk-return features to those in other sectors.

Wurstbauer and Schafers (2015) and Finkenzeller (2012) noted that few academic studies had been conducted on the infrastructure sector in general, and particularly on volatility features in emerging markets. Publications by investment professionals and companies have employed basic statistical approaches (like standard deviation and mean return) to analyze the volatility profile of this sector. Moreover, most of these studies (biased towards industrial bulletins) have been confined to developed nations. The current study sought to fill this methodological and geographical gap.

The study investigated the volatility features of the infrastructure sector in emerging nations where industrialization, urbanization, and population growth, coupled with economic growth, have heightened demand for infrastructure. Emerging markets are in critical need of infrastructure investment. Indeed, the World Bank (2018) notes that demand outstrips supply to the tune of USD 1.3 trillion per annum. An empirical investigation of the volatility features of infrastructure investments in emerging markets is of interest to investors and policy-makers as they design investment policies and formulate infrastructure concessions in an attempt to spur infrastructure provision and reduce the ever-growing gap in emerging economies (Mashamba \& Magweva, 2019).

The volatility features examined in the study included volatility persistence, volatility clustering, and leverage effects. Volatility persistence indicates the degree to which a shock on the variable under investigation lasts (Uyaebo et al., 2015). When a variable exhibits significant volatility persistence, this implies that once a shock is introduced, it will take time to expire or to be reduced. In other words, the variable price will swing up and down for a prolonged period of time, which is undesirable for investors, consumers, and policy-makers (Takemura et al.,2019). The opposite is true for variables with low volatility persistence, which is desirable for investors and economic growth as it makes planning and forecasting easier.

Leverage effects imply an asymmetric response of conditional variance (volatility) to changes or shocks by the variable under study. The existence of leverage effects indicates that the effect of negative news on future conditional variance or volatility is greater than the effect of positive news of the same magnitude (Gahlot, Datta \& Kapil, 2010). In other words, the future volatility of the variable's responses depends more on negative than positive shocks, implying a negative relationship between current variable changes and future variable volatility. Transposed to market returns, volatility, or conditional variance rises more rapidly when market returns are decreasing than when they are increasing (Aydemir, Gallmeyer, \& Hollifield, 2006; Owidi \& Mugo-Waweru, 2016). Value-at-risk computations must be adjusted for the presence of leverage effects; otherwise, the value will be underestimated (Engle, 2004). In the same vein, stock market investors require a premium as compensation for uncertainty if leverage effects are exhibited. 
Reverse volatility asymmetry arises when positive news (increased returns) impacts more than negative news (a fall in returns) on the future conditional volatility of the variable under study (stock returns). The absence of leverage effects and reverse volatility asymmetry indicates a symmetric response to positive and negative news - with the same and equal effect on conditional variance (Ghalot et al., 2010).

The remainder of this paper is structured as follows: The second section reviews the literature on the infrastructure sector, while section three discusses the data and methods employed in this study. Section four presents and discusses the findings, and section five provides an overall conclusion and recommendations to investors and policy-makers.

\section{Literature review}

As noted earlier, there is a paucity of academic research on the infrastructure sector, let alone on the phenomenon of volatility in emerging nations. Blanc-Brude (2015) noted that infrastructure sector returns are less volatile than those in other sectors as demand for its products and services is inelastic and less responsive to economic and business cycles. Firms operating in this sector provide utilities and essential services, which in most cases, have no readily available substitutes. The infrastructure sector thus enjoys pricing powers which can be manipulated to protect its earning power in the short and long run. Moss (2014) notes that the sector is characterized by monopolistic or oligopolistic features, inelastic demand, predictable and stable cash inflows, high operating margins, and long asset life. Given that this information is publicly available, we would expect that infrastructure sector stocks would earn steady, less volatile returns, assuming informationally efficient financial markets.

However, the deregulation drive in most emerging markets is undermining the pricing powers of the infrastructure sector (Swedroe, 2013). At the same time, infrastructure sector stocks might deviate from their fundamental value due to investor irrationality and the existence of inefficient capital markets. Consequently, stock returns might be just as volatile and unsteady as general listed stocks.

Bahceci and Weisdorf's (2014) empirical study on infrastructure cash flows in the US, and Western Europe noted that such assets are less volatile than traditional assets. Kempler (2016) and Babson (2013) employed global indices to show that listed infrastructure exhibited lower volatility than global property, and global common equity.

However, to the best of the authors' knowledge, no study has been published on the volatility aspects of the infrastructure sector in both developing and developed nations. The current study is thus a pioneer one on infrastructure sector volatility behaviour in emerging markets. 
Modeling and Forecasting the Volatility of Returns in the Infrastructure Sector in Emerging ..

Previous studies on stock markets, in general, indicated the existence (and absence) of leverage effects and volatility persistence. Table 1 presents a snapshot of such studies.

\section{Table 1. Snapshot of studies on stock market volatility}

\begin{tabular}{lll}
\hline Author(s) & Nation(s) & Conclusions \\
\hline $\begin{array}{l}\text { Banumathy \& Azhagaiah (2015); } \\
\text { John \& Amudha (2019) }\end{array}$ & India & Leverage effects \\
\hline Yeh \& Lee (2000) & China & Reverse volatility asymmetry \\
\hline Jingli \& Sheng (2011); Hou (2013) & China & Leverage effects \\
\hline Mashamba \& Magweva (2019) & Southern Africa & Leverage effects and volatility asymmetry \\
\hline Okpara \& Nwezeaku (2009) & Nigeria & Less volatility persistence and leverage effects \\
\hline Guidi (2008) & Europe & Leverage effects \\
\hline Kalyanaraman (2014) & Saudi Arabia & Volatility clustering, persistence \\
\hline Dana (2016) & Amman & Symmetric response \\
\hline
\end{tabular}

Source: Authors' compilation

While the current study focused on the infrastructure sector, the results of past studies on different stock markets suggested the results and conclusions that could be expected.

\section{Methodology}

This section outlines the data and the models used to examine the volatility behaviour of the infrastructure sector in emerging nations.

\subsection{Data and data source}

This empirical study used the Standard and Poor Emerging Markets Infrastructure Daily Total Return Index as a proxy for infrastructure sectors in emerging markets from July 1, 2009 to July 1, 2019 (2 605 observations). The index tracks 30 listed and liquid emerging market infrastructure companies in the utilities, transport and energy clusters. The total return index includes interest, dividends, and other distributions, such as rights issues, realized over a period of time. It is the new benchmark when it comes to assessing the performance of mutual funds and investment managers at large.

The following formula was used to convert the daily total return index into daily continuously compounded returns (in percentages):

$$
R_{t}=\ln \left(P_{t} \mid P_{t-1}\right) * 100
$$

where $P_{t}$ and $P_{t-1}$ are the closing index on day $t$ and $t-1$, respectively, and $R_{t}$ is the infrastructure sector return on day $t$.

\subsection{Empirical model}

In establishing the volatility behaviour of the infrastructure sector in emerging economies, the study adopted the Exponential Generalized Autoregressive Conditional Heteroscedasticity (EGARCH) and Glosten-Jaganathan and Runkle (GJR) 
GARCH (equivalent to Threshold GARCH) first-order models $(1,1)$ using normal and non-normal error distributions (Student's $t$, and generalized error distribution (GED)). Mashamba and Magweva (2019) and Ekong and Onye (2017) note that GARCH models fail to account for all leptokurtosis in the data if the conditional variance does not follow the normal distribution, thereby rendering the model inefficient.

The most common models of volatility/variance assume that volatility is constant over time (Fabozzi et al., 2014). Empirically, this assumption has been disputed. Highfrequency financial data is usually heteroskedastic, often exhibiting volatility clustering and leptokurtosis as well as leverage effects (Ekong \& Onye, 2017). This invalidates the use of linear models in volatility estimation (Banumathy \& Azhagaiah, 2015). As such, volatility is now commonly estimated using the GARCH model and its variants. The GARCH model propounded by Bollerslev (1986) is an extension of the ARCH model (attributed to Engle, 1982), which stipulates that volatility tends to be time-variant and clustered, especially in the stock market data.

In estimating the ARCH family models, the first step is to check the stationarity level to confirm the mean reversion presence or absence (John \& Amudha, 2019). The second procedure involves estimating the best fitting conditional mean equation (Dana, 2016). The conditional mean equation follows the Auto Regressive Moving Average (ARMA) model, expressed as follows:

$$
R_{t}=\beta R_{t-1}+\varepsilon_{t}+\lambda \varepsilon_{t-1}
$$

where $\mathrm{R}_{\mathrm{t}}$ is the infrastructure sector returns, and $\varepsilon$ is the usual error. The Akaike information criterion (AIC) was used to determine the appropriate lag length to include in the mean equation using the 'varsoc' command in Stata.

After estimating the mean equation, the presence of 'ARCH effects' is examined. The existence of 'ARCH effects' calls for the econometric use of ARCH family models (John \& Amudha 2019), while the absence of such effects in the residuals renders an ARCH model pointless and misspecified. The use of ARCH family models is legitimized by the presence of autocorrelation of variance or heteroscedasticity, volatility clustering, excess kurtosis, and skewness.

In the ARCH model the conditional variance, $\sigma_{t}^{2}$, is dependent on lagged values of the squared error $(u)$. Thus:

$$
\sigma_{t}^{2}=\alpha_{0}+\alpha_{1} u_{t-1}^{2}
$$

Considering the GARCH $(1,1)$ model, which is widely employed, the conditional variance is determined by own lags and the lagged squared error terms $(u)$. This is represented as follows:

$$
\sigma_{t}^{2}=\alpha_{0}+\alpha_{1} u_{t-1}^{2}+\beta \sigma_{t-1}^{2}
$$

The weakness of the GARCH model hinges on its assumption of symmetry, implying that positive (good news) and negative shocks (bad news) have an equal effect on 
conditional variance in the model (Ekong \& Onye, 2017). To counter this, Nelson (1991) proposed the EGARCH $(1,1)$ model, which was adopted in this study. As specified by Banumathy and Azhagaiah (2015) and Coffie (2015), the EGARCH $(1,1)$ model can be represented as follows:

$$
\log \left(\sigma_{t}^{2}\right)=\alpha_{0}+\beta_{1} \log \left(\sigma_{t-1}^{2}\right)+\alpha_{1}\left|\frac{u_{t-1}}{\sigma_{t-1}}\right|+\lambda_{1} \frac{u_{t-1}}{\sigma_{t-1}}
$$

where $\left(\sigma_{t}^{2}\right)$ the variance is at time $t$, and $u$ is the disturbance term, whereas $\alpha$ and $\beta$ are empirical parameters determined by maximum likelihood estimation. The $\alpha$ parameter captures a magnitude effect or the symmetric effect of the model, the 'GARCH' effect. The persistence of shocks to the volatility is captured by $\beta$ under the EGARCH model. The parameter $\lambda$ captures the impact of news on future volatility of the infrastructure sector. If $\lambda$ is negative and significant (where $\lambda_{1}<0$ ), it indicates the presence of leverage effects. If it is positive and significant $\left(\lambda_{1}>0\right)$, it indicates the existence of reverse volatility asymmetry. The effect is symmetric if $\lambda_{1}=0$.

The GJR-GARCH (similar to the TGARCH model) was another asymmetric GARCH model adopted in this study. The model is specified as follows:

$$
\sigma_{t}^{2}=\alpha_{0}+\alpha_{1} u_{t-1}^{2}+\beta \sigma_{t-1}^{2}+\gamma u_{t-1}^{2} I_{t-1}
$$

where, $I_{t-1}$ is the dummy variable assuming the values of 0 and 1 . The dummy variable is equal to 1 if $u_{t-1}^{2}$ is less than 0 (the shock is negative) and 0 otherwise. If the parameter $\gamma$ is positive and significant, leverage effects exist.

\subsection{Forecasting}

The dynamic forecasting method was used to evaluate the forecasting ability of the adopted models. More specifically, mean squared errors (MSE), and root mean square error (RMSE) loss functions were used in this study. The MSE, which penalizes large forecast errors more severely than other common accuracy measures is determined as follows:

$$
M S E=\sum_{t}^{n} \frac{e_{t}^{2}}{n}
$$

For which $e_{t}=\mathrm{y}_{t}-\hat{\mathrm{y}}_{t}$ where $\mathrm{y}_{\mathrm{t}}$ is the actual value observed in time $t$ and $\hat{\mathrm{y}}_{\mathrm{t}}$ is the fitted value in time $t$.

The RMSE, which is favored by academics and practitioners, is expressed as follows:

$$
R M S E=\sqrt{\sum_{t}^{n} \frac{e_{t}^{2}}{n}}
$$

The lower the value of the loss function, the greater the forecasting efficiency of the model under consideration. 


\section{Results and findings}

This section presents and discusses the results obtained using the above models on the volatility features of the infrastructure sector in emerging markets.

\subsection{Preliminary analysis}

The distributional features, including first, second, third, and fourth moments of listed infrastructure sector returns in emerging nations, are presented in Table 2.

Table 2. Descriptive statistics

\begin{tabular}{lllllllll}
\hline & Mean & Max & Min & Std. dev & Skewness & Kurtosis & J-B & Prob \\
\hline Return & 0.0181 & 5.4538 & -6.43396 & 0.9573 & -0.3587 & 6.4975 & 1383 & 0.000 \\
\hline
\end{tabular}

Source: Extract from E-views

On average, infrastructure sector stock investors earned $0.0181 \%$ daily. The JarqueBera probability is significant at $1 \%$, indicating the non-normal distribution of infrastructure stock returns in emerging markets. Evidence of heteroscedasticity is exhibited by the existence of excess kurtosis (6.4975, which is bigger than 3 ). As indicated by the skewness value $(-0.3587)$, the returns were negatively skewed during the period under study.

\subsection{Stationarity tests}

To ascertain the order of integration, the study applied three unit-root (and stationarity) tests to validate the results. The results are displayed in Table 3 . The Augmented Dickey-Fuller (ADF) test (which is based on parametric transformation), the Phillips-Perron (PP) test (a non-parametric test that addresses the serial correlation in the error-terms) and the Kwiatkowski-Phillips-Schmidt-Shin (KPSS) test, all attest to the stationarity in levels of infrastructure sector daily stock returns in emerging markets.

Table 3. Stationarity tests results

\begin{tabular}{lll}
\hline & T-statistic & Decision \\
\hline ADF & -42.192 & Stationary in levels - I(0) \\
\hline Phillips-Perron & -41.794 & Stationary in levels - I(0) \\
\hline KPSS & 0.1034 & Stationary in levels - I(0) \\
\hline
\end{tabular}

Source: Authors' extracts from Eviews

The findings are in tandem with the financial literature that specifies that stock returns tend to be stationary in levels as the returns are effectively derivatives of stock prices (normally integrated of order one).

\subsection{Testing for 'ARCH' effects}

To validate the use of the ARCH family models, the study tested for the presence of 'ARCH effects' using graphical and statistical methods. Volatility clustering is clearly exhibited in Figure 1 below as periods of high volatility are followed by periods of high volatility, and periods of low volatility are followed by periods of low volatility. 
Modeling and Forecasting the Volatility of Returns in the Infrastructure Sector in Emerging ..

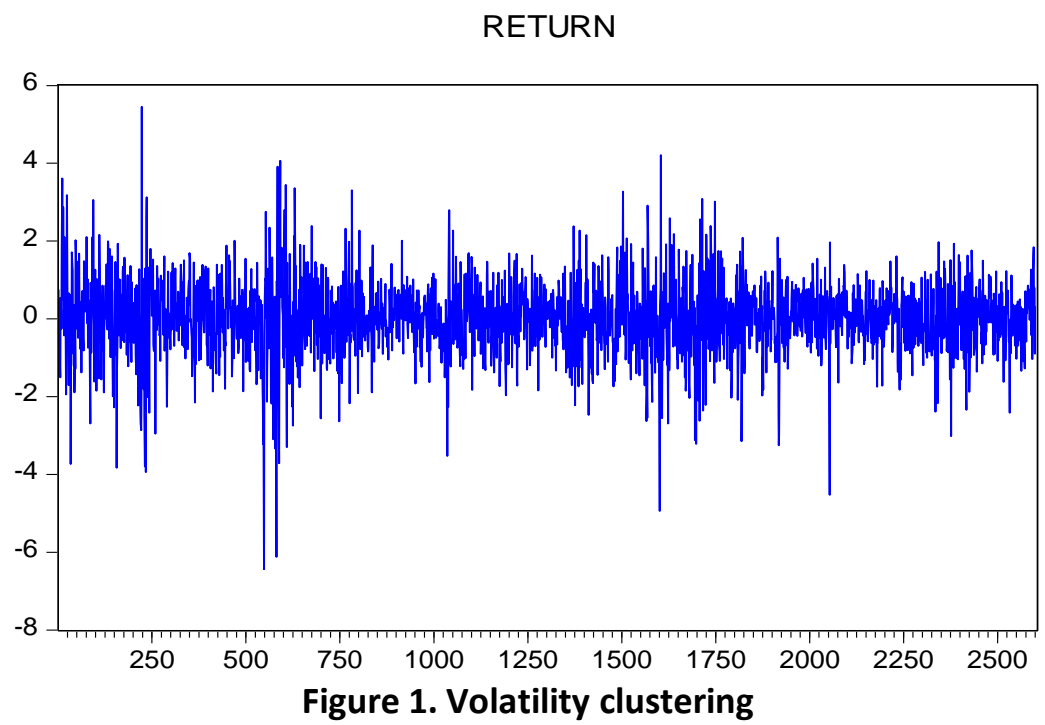

Source: Authors' extract from Eviews

Excess kurtosis, skewness, and non-normality of the returns (see Table 2) all point to the validity of the ARCH models. The ARCH test was used on the residuals from the mean equation (ARMA 4,4 model), and the results are shown in Table 4.

Table 4. Heteroskedasticity Test: ARCH

\begin{tabular}{ll|ll}
\hline F-statistic & 44.032 & Prob. F(1,2597) & 0.000 \\
\hline Obs*R-squared & 43.331 & Prob. Chi-Square(1) & 0.000 \\
\hline
\end{tabular}

Source: Authors' extract from Eviews

It can be safely concluded that the errors are not homoscedastic, thereby further validating the appropriateness of the ARCH models.

\subsection{EGARCH and GJR-GARCH models estimation results}

This section outlines the results obtained from estimating the EGARCH and GJRGARCH models of order 1 . The results of the variance equation employing the EGARCH $(1,1)$ model using three error distributions are presented in Table 5.

Table 5. EGARCH $(1,1)$ estimation results

\begin{tabular}{llll}
\hline & Normal & Student's T & GED \\
\hline $\mathrm{C}$ (constant) & $-0.0999^{*}$ & $-0.0794^{*}$ & $-0.0896^{*}$ \\
\hline$\alpha$ (garch effects) & $0.11999^{*}$ & $0.0948^{*}$ & $0.1069^{*}$ \\
\hline$\lambda$ (leverage effects) & $-0.0712^{*}$ & $-0.0630^{*}$ & $-0.0655^{*}$ \\
\hline B (volatility persistence) & $0.9766^{*}$ & $0.9832^{*}$ & $0.9802^{*}$ \\
\hline
\end{tabular}

Source: Authors' extracts from Eviews. * indicates significance at $1 \%$ level of significance

Considering all error distributions, the GARCH effects are positive and significant in emerging markets' infrastructure stock returns, implying that past volatility is 
significant in predicting current volatility. Emerging markets' infrastructure sector returns have a significant response to the absolute size of the shock. This is in harmony with Kalyanaraman (2014) and Mashamba and Magweva (2019), who noted the existence of GARCH effects in Saudi Arabian and Southern African stock markets, respectively. The level of volatility persistence is very high (0.97656) and significant, indicating that once a shock is introduced to the infrastructure sector in emerging markets, it takes time to die out - it has a long memory. This persistence is normally attributed to market inefficiency (whereby information is slowly assimilated and captured in stock prices) and the momentum effect - which is a behavioural bias. Financial market participants, particularly risk-averse investors, respond irrationally to any piece of information that purports to erode the value of their investments (Wilson et al., 2019).

A large number of investors (local and foreign) in emerging markets implies different market analysis methods, as well as different beliefs and forecasts strategies. Such variation promotes 'noise' in the market, accentuating volatility persistence as heterogeneous investors and fund managers (including necromancers) capture news in stock prices (Mashamba \& Magweva, 2019).

The leverage effect coefficient is negative $(-0.07122)$ and significant, indicating the existence of an asymmetric response to bad (negative) and good (positive) news by investors in emerging markets' infrastructure sector. A negative relationship exists between past returns and current conditional variance in the infrastructure sector in emerging markets. In other words, the effect of negative news on future volatility is greater than the impact of positive news of the same size. This is contrary to the conclusions reached by Dana's (2016) study on the Amman stock exchange, Oskooe and Shamsaravi's (2011) research on Iran's stock market and Niyitegeka and Tewari's (2013) analysis of the South African stock market that noted the absence of asymmetric effects.

The results from the GJR-GARCH assuming different distributions are shown in Table 6.

\section{Table 6. GJR-GARCH $(1,1)$ estimation results}

\begin{tabular}{llll}
\hline & Normal & Student's T & GED \\
\hline $\mathrm{C}$ (constant) & $0.04571^{*}$ & $0.01998^{*}$ & $0.0216^{*}$ \\
\hline arch term & $0.03617^{*}$ & $0.02432^{*}$ & $0.0251^{*}$ \\
\hline$\lambda$ (leverage effects) & $0.11879^{*}$ & $0.07146^{*}$ & $0.0774^{*}$ \\
\hline garch term & $0.84658^{*}$ & $0.91379^{*}$ & $0.9079^{*}$ \\
\hline
\end{tabular}

Source: Authors' extract from Eviews. *indicates significance at $1 \%$ level of significance

The above results are in line with those obtained using the EGARCH model, i.e., significant volatility persistence, leverage effect, $A R C H$ term, and GARCH term. They concur with John and Amudha (2019) and Coffie (2015), although these authors did not specifically examine the infrastructure sector. However, they contradict the 
Modeling and Forecasting the Volatility of Returns in the Infrastructure Sector in Emerging ..

conclusions reached by Saleem (2007) and Aliyu (2011), who noted the existence of reverse asymmetric volatility.

The existence of significant volatility persistence in emerging markets' infrastructure stock returns implies that shocks on the sector take time to die out, thus making volatility predictions worthwhile. This might be of assistance to investors, firms, and money managers interested in making hedging and speculating decisions on volatility in the infrastructure sector in emerging markets.

However, stock market investors tend to demand a higher risk premium in the face of volatility persistence. This translates into higher costs of capital, high bid-ask spreads, and increased costs of providing liquidity, all leading to depressed private and foreign direct investment in the infrastructure sector in emerging markets compared to developed markets (Emenike, 2010). Infrastructure firms operating in emerging markets are negatively affected by the existence of volatility persistence as they require significant reserves of cash and cash-equivalent assets in order to assure creditors and other stakeholders of their stability and soundness (Ndwiga \& Muriu, 2016). Consequently, the value attached to firms in the infrastructure sector in emerging markets is comparatively lower than those in stable and efficient financial environments of the developed markets. Stock market development is threatened when significant volatility persistence is exhibited, although abnormal returns can be earned.

The existence of leverage effects was notable in both models, implying that stock market participants in the infrastructure sector tend to over-react to negative news/shocks and under-react to positive news. In other words, volatility responds more to negative shocks than positive shocks of the same size. The leverage effect is attributable to 'noisy' uninformed and irrational investors in such markets (Avramov et al., 2007). The fact that the leverage effects and GARCH effects are both significant implies that as the asymmetric impact of innovations is accounted for, the absolute size of the innovation is equally important.

\subsection{The forecasting ability of models}

After ascertaining the diagnostic stability and appropriateness of both models, dynamic forecasts were performed, and the results thereof are presented in this section. The loss function values from the EGARCH forecasts are presented in Table 7.

Table 7. EGARCH loss function values

\begin{tabular}{llll}
\hline & Normal & Student's T & GED \\
\hline RMSE & 0.9572 & 0.9572 & 0.95713 \\
\hline MAE & 0.7020 & 0.7015 & 0.70149 \\
\hline
\end{tabular}

Source: Authors' compilation

The distribution providing the best forecast under the EGARCH model is the GED. The loss function results from GJR GARCH model are shown in Table 8. 
Table 8. GJR-GARCH model loss function values

\begin{tabular}{llll}
\hline & Normal & Student's T & GED \\
\hline RMSE & 0.9570 & 0.9570 & 0.9564 \\
\hline MAE & 0.7014 & 0.7011 & 0.7006 \\
\hline
\end{tabular}

Source: Authors' compilation

The GJR-GARCH model performs best under the GED in comparison to other distributions. This is in tandem with the results obtained from the EGARCH forecasts. From the estimates made, the GJR-GARCH model performs better than the EGARCH models in all error distributional assumptions. This is based on slightly lower loss function values from the GJR-GARCH model compared to EGARCH with slightly higher loss function values.

\section{Conclusion and recommendations}

Understanding the dynamic volatility behaviour of infrastructure sector returns in emerging markets is paramount in the face of the ever-increasing infrastructure deficit and financial market instability. Comprehending the volatility behaviour of specific sectors of the economy enables investors to formulate workable investment strategies and policy-makers to design policies that dampen excess volatility. The study laid bare the volatility features of the infrastructure sector in emerging markets. The stylized features assessed were the GARCH effects, volatility persistence and leverage effects. This study used EGARCH and GJR-GARCH models of order one under normal and non-normal error distributions to unpack the volatility behaviour of infrastructure returns in emerging markets.

The results from both models under all distributions indicated the existence of GARCH effects, volatility clustering, volatility persistence, and leverage effects in the infrastructure sector in emerging nations. They imply that past conditional variance is significant in determining current conditional variance, thereby making forecasting a worthwhile undertaking. The existence of volatility clustering means that periods of high (low) volatility or swings are followed by periods of high (low) volatility in the infrastructure sector in emerging markets. Once introduced into the financial market, volatility from the infrastructure sector takes time to decay. The impact of negative news on future conditional volatility is larger than that of positive news. This asymmetry is amplified by the existence of irrational and uninformed traders who overact to negative news and underreact to positive news.

The exhibited volatility features imply that investors interested in the infrastructure sector in emerging markets should incorporate leverage effects in their estimation of value-at-risk (otherwise, the value will be underestimated). It is also recommended that investors go beyond mean-variance portfolio optimization and consider leverage effects, excess kurtosis, and skewness when making investment decisions. Investors in the infrastructure sector in emerging markets should also formulate hedging strategies as they are exposed to significant risk and uncertainty. 
Modeling and Forecasting the Volatility of Returns in the Infrastructure Sector in Emerging ..

Corporates in the infrastructure sector in emerging markets should be prepared to absorb an additional risk premium as lenders are exposed to significant volatility persistence, an illiquid sector, and increased anxiety. It is recommended that financial regulators in emerging markets should formulate policies which address the identified volatility features. On the same note, policy-makers should try by all means to reduce negative news emanating from policy inconsistencies, macroeconomic instability, and political instability. The regulatory authorities are encouraged to design policies that promote a well-functioning, stable financial environment to spur economic growth. Otherwise, investors will require a risk premium, increasing the cost of capital and hampering the availability of long-term capital, thereby dampening nations' economic growth prospects. To add on, the exhibited volatility persistence negatively affects investment decisions and undermines the price stability role of monetary authorities, thus affecting economic growth. As such, regulatory authorities are recommended to formulate policies and economic environments with instill investor confidence and dampens financial market volatility.

Given the heterogeneous nature of emerging markets, further research could include country-by-country analysis. In-depth sub-sector analysis could also offer significant insights into volatility behaviour in the infrastructure sector in emerging markets. As data becomes increasingly available, evaluating the volatility features of unlisted infrastructure might provide useful insights and conclusions.

\section{References}

Aliyu, S.U.R. (2011). Does inflation have an impact on stock returns and volatility? Evidence from Nigeria and Ghana. Applied financial economics, 22(6), 427-435. https://doi.org/10.1080/09603107.2011.617691

Avramov, D., Chordia, T., Jostova, G. \& Philipov, A. (2007). Momentum and credit rating. The Journal of Finance 62(5), 2503-2520. https://doi.org/10.1111/j.1540-6261.2007.01282.x

Aydemir, A.C., Gallmeyer, M. \& Hollifield, B. (2006). Working paper no. 263, Society for Economic Dynamics, Edinburgh. Financial leverage does not cause the leverage effect. https://doi.org/10.2139/ssrn.890609

Babson, A. (2013, August, 20). Listed infrastructures as an equity diversifier. Russell Investments.

Bahceci, S., \& Weisdorf, M. (2014). The investment characteristics of OECD infrastructure: A cash flow analysis, Rothan International Journal of Pension Management, 7 (1). Retrieved from http://www.rijpm.com/admin/article files/Weisdorf to Post.pdf

Banumathy, K. \& Azhagaiah, R. (2015). Modelling stock market volatility: evidence from India. Managing Global Transitions, 13(1), 27-42. https://doi.org/10.12816/0019391

Blanc-Brude, F., (2015), Long horizon investing in infrastructure. The journey from investment beliefs to investment delegation and benchmarking. A presentation prepared for the June 2015, ICPM Discussion Forum EDHEC-Risk Institute.

Bollerslev, T. (1986). Generalized autoregressive conditional heteroscedasticity. Journal of econometrics, 31(3), 307-327. https://doi.org/10.1016/0304-4076(86)90063-1 
Coffie, W. (2015). Measuring volatility persistence and risk in Southern and East African stock markets. International Journal of Economics and Business Research, 9(1), 23-36. https://doi.org/10.1504/IJEBR.2015.066009

Dana, A. (2016), Modelling and Estimation of Volatility Using ARCH/GARCH Models in Jordan's Stock Market. Asian Journal of Finance \& Accounting, 8,(1). https://doi.org/10.5296/ajfa.v8i1.9129

Ekong, C.N., \& Onye, K.U. (2017). Application of Garch Models to Estimate and Predict Financial Volatility of Daily Stock Returns in Nigeria. International Journal of Managerial Studies and Research (IJMSR) 5(8), 18-34. Retrieved from: https://doi.org/10.20431/2349$\underline{0349.0508003}$

Emenike, K. O. (2010). Modelling stock returns volatility in Nigeria using GARCH models, Munich Personal Paper Publications, No. 23432.

Engle, R. F. (1982). Autoregressive conditional heteroscedasticity with estimates of the variance of United Kingdom inflation. Econometrica, 50(4), pp. 987-1007. https://doi.org/10.2307/1912773

Engle, R. (2004). Risk and volatility: Econometric models and financial practice. The American Economic Review, 94(3), 405-420. https://doi.org/10.1257/0002828041464597

Fabozzi, F.J., Focardi, S.M., Rachev, S.T., \& Arshanapalli, B.G. (2014). The basics of financial econometrics - tools concepts and asset management applications. John Wiley \& Sons, Inc., Hoboken, New Jersey, NJ.

Finkenzeller, K. (2012). Essays in Infrastructure Investment. (PhD Thesis). Retrieved from https://epub.uniregensburg.de/31296/1/fsprofilexenapp\%24Ordnerumleitung2383Desktop Master\%20FoulderDissertationFinalversionAbgabe.pdf

Gahlot, R., Datta, S.K., \&, Kapil, S. (2010). Impact of derivative trading on stock market volatility in India: A study of S\&P CNX Nifty. Eurasian Journal of Business and Economics, 3 (6), 127-137.

Glosten, L. R., Jagannathan, R. \& Runkle, D. E. (1993). On the relations between the expected value and the volatility of the nominal excess returns on stocks. Journal of Finance, 48(5), 1779-1801. https://doi.org/10.1111/j.1540-6261.1993.tb05128.x

Guidi, F. (2008). MPRA (Munich Personal RePEc Archive) Paper No. 11535, Volatility and Long Term Relations in Equity Markets: Empirical Evidence from Germany, Switzerland, and the UK. Retrieved from http://mpra.ub.uni- muenchen.de/11535/

Hou, A J. (2013). Asymmetry Effects of Shocks in Chinese Stock Markets Volatility: A Generalized Additive Nonparametric Approach. Journal of International Financial Markets, Institutions and Money, 23, 12-32. https://doi.org/10.1016/i.intfin.2012.08.003

Islam, M. (2013). Estimating Volatility of Stock Index Returns by Using SymmetricARCH Models. Middle East Journal of Scientific Research, 18(7), 991-999.

Jingli, X., \& Sheng, Z. (2011). Stock Market Volatility in China - Based on the Model of ARIMAEARCH-M $(1,1)$ and ARIMA-TARCH-M $(1,1)$. Journal of Management Science \& Statistical Decision, 8(1). https://doi.org/10.1007/978-3-642-23065-3 75

John, J.K. \& Amudha, R. (2019). Asymmetric Volatility Modeling and Leverage Effect of Nifty Stocks, International Journal of Innovative Technology and Exploring Engineering 8(6).

Kalyanaraman, L. (2014). Stock Market Volatility in Saudi Arabia: An Application of a Univariate GARCH Model. Asian Social Science, 10(10), 142-152. https://doi.org/10.5539/ass.v10n10p142 
Modeling and Forecasting the Volatility of Returns in the Infrastructure Sector in Emerging ..

Kempler, S. (2016, August). The role of infrastructure in a portfolio Global Listed Infrastructure. Maple-Brown-Abbott. Retrieved from https://www.maplebrownabbott.com.au/Documents/Insights/press-release-aug-2016.pdf

Mashamba, T. \& Magweva, R. (2019). Dynamic volatility behaviour of stock markets in Southern Africa. Journal of Economic and Financial Sciences 12(1), https://doi.org/10.4102/jef.v12i1.396

Moss, A. (2014, September). Infrastructure investment: combining listed with unlisted. Consilia Capital. https://doi.org/10.2139/ssrn.2616634

Ndwiga, D. \& Muriu, P.W. (2016). Stock returns and volatility in an emerging equity market. Evidence from Kenya. European Scientific Journal 12(4),79-98. https://doi.org/10.19044/esj.2016.v12n4p79

Nelson, D.B. (1991). Conditional heteroscedasticity in asset returns: A new approach. Econometrica, 59(2), 347-370. https://doi.org/10.2307/2938260

Nguyen, A.T. (2019). The relationship between economic growth, energy consumption and carbon dioxide emissions: Evidence from Central Asia. Eurasian Journal of Business and Economics, 12(24), 1-15. https://doi.org/10.17015/ejbe.2019.024.01

Niyitegeka, O. \& Tewar, D.D. (2013). Volatility clustering at the Johannesburg Stock Exchange: Investigation and analysis. Mediterranean Journal of Social Sciences, 4(14), 621-626. https://doi.org/10.5901/mjss.2013.v4n14p621

Okpara, G. C., \& Nwezeaku, N. C. (2009). Idiosyncratic risk and the cross-section of expected stock returns: Evidence from Nigeria. European Journal of Economics, Finance and Administrative Sciences, 17(2), 1-10.

Oskooe, S.A.P. \& Shamsavari, A. (2011). Asymmetric effects in emerging stock markets -The case of Iran stock market. International Journal of Economics and Finance, 3(6), 16-24. https://doi.org/10.5539/ijef.v3n6p16

Owidi, O.H. \& Mugo-Waweru, F. (2016). Analysis of asymmetric and persistence in stock return volatility in the Nairobi Securities Exchange market phases. Journal of Finance and Economics, 4(3), 63-73.

Pati, P.C., Barai, P., \& Rajib, P. (2018). Forecasting stock market volatility and information content of implied volatility index. Applied Economics, 50(23) 2552-2568 https://doi.org/10.1080/00036846.2017.1403557

Rahahleh, N., \& Kao, R. (2018). Forecasting Volatility: Evidence from the Saudi Stock Market, Journal of Risk Financial Management, 11(4). https://doi.org/10.3390/jrfm11040084

Saleem, K. (2007). Modeling Time Varying Volatility and asymmetry of Karachi Stock Exchange (KSE). International Journal of Economic Perspectives, 1(1), 1-14.

Swedroe, L. (2013, June 24). Swedroe: Infrastructure As Inflation Hedge-Not. Retrieved from: https://www.etf.com/sections/index-investor-corner/19041-swedroe-infrastructure-asinflation-hedgenot.html

Takemura, T., Kozu, T., Takeda, K., \& Suehiro, T. (2018). Positive analysis on Japanese individual investors' ratio of risk asset holding. Eurasian Journal of Business and Economics, 11(21), 69-85. https://doi.org/10.17015/ejbe.2018.021.04

Uyaebo, S. O., Atoi, V. N., \& Farida, U. (2015). Nigeria stock market volatility in comparison with some countries: Application of asymmetric GARCH models. Journal of Applied Statistics, 6(2), 133-160. 
Wilson E. H., Ugwuanyi, G.O., \& Nwaocha, E.I. 2019. Volatility Clustering, Leverage Effects and Risk-Return Trade-Off in the Nigerian Stock Market. Journal of Finance and Economics, 7(1) 113.

World Bank (2018, February 02). Infrastructure Finance. Retrieved from https://www.worldbank.org/en/topic/financialsector/brief/infrastructure-finance

Wurstbauer, D., \& Wolfgang, S. (2015). Inflation hedging and protection characteristics of infrastructure and real estate assets. Journal of Property Investment \& Finance, 33 (1) 19 - 44. https://doi.org/10.1108/JPIF-04-2014-0026

Yeh, Y., \& Lee, T. (2000). The interaction and volatility asymmetry of unexpected returns in the greater China stock markets. Global Finance Journal 11, 129-149. https://doi.org/10.1016/S1044-0283(00)00014-4 